\title{
エリスリナおよび関連アルカロイドの合成
}

\author{
佐 野 武 弘*・津 田喜 典**
}

\section{Syntheses of Erythrina and Related Alkaloids.}

Takehiro SANO $*$ and Yoshisuke TSUDA $* *$

This article describes the synthetic studies of Erythrina and related alkaloids including i) construction of erythrinan and homoerythrinan skeletons, ii) total syntheses of erythrinan alkaloids, iii) total syntheses of homoerythrinan alkaloids, and iv) syntheses of non-benzenoid erythrinan skeletons.

\section{1. 緒論}

マメ科 Erythrina 属植物より得られるエリスリナアル カロイドは, 経口投与でクラーレ様の筋弛緩作用を示す ことで注目されている。エリスリナアルカロイドの基本 骨格は hydroindole 環と tetrahydroisoquinoline 環が一つ のスピロ炭素を共有して縮合した構造を有している。こ の骨格を持つ代表的なアルカロイドとして, erysotrine 1, erysodine 2, erythraline 3, erysotramidine 4, erythramine 5, erythratidine 6, erythratidinone 7 など が挙げられる。

その後同様の構造のアルカロイドがッヅラフジ科 Cocculus 属からも見出されており, さらに同様の構造
的特徽を持っているが, D 環の芳香環がラクトン環とな った非芳香族群として $\beta$-erythroidine 8 や cocculolidine 9 などが知られている。また， C 環が七員環となったい わゆるホモエリスリナアルカロイドとよばれる一群がユ リ科 Schelhammera 属, モチノキ科 Phelline 属, イヌガ ヤ科 Cephalotaxus 属, スギ科 Anthrotaxis 属, センダン 科 Dysoxylum 属植物から見い出され，植物界における 分布はエリスリナアルカロイドよりも広いのではないか と思える。Schelhammeridine 10 や schelhammericine 11 などがその例である。

これらのアルカロイドは $\mathrm{A}, \mathrm{B}$ 環に存在する官能基で も分類され, dinenol 構造を持つものを dienoid 型, 二重結 合 1 個の構造を持つものを alkenoid 型とよんでいる1)。

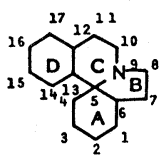

Erythrinan

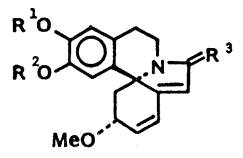

$\begin{array}{lll}\mathrm{R}^{1} & \mathrm{R}^{2} & \mathrm{R}^{3} \\ \mathrm{CH}_{3} & \mathrm{CH}_{3} & \mathrm{H}_{2}\end{array}$

$\begin{array}{llll}1 & \mathrm{CH}_{3} & \mathrm{CH}_{3} & \mathrm{H}_{2} \\ 2 & \mathrm{H} & \mathrm{CH} & \end{array}$

$\begin{array}{llll}2 & \mathrm{H} & \mathrm{CH}_{3} & \mathrm{H}_{2}\end{array}$

$3-\mathrm{CH}_{2}$

$4 \mathrm{CH}_{3} \quad \mathrm{CH}_{3} \quad \mathrm{O}$

Dienoid type

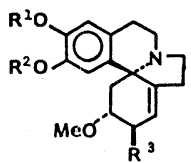

\begin{tabular}{llll} 
& $\mathrm{R}^{1}$ & $\mathrm{R}^{2}$ & $\mathrm{R}^{3}$ \\
\hline 5 & $-\mathrm{CH}_{2}$ & $\mathrm{H}$ \\
6 & $\mathrm{CH}_{3}$ & $\mathrm{CH}_{3}$ & $\mathrm{OH}$ \\
7 & $\mathrm{CH}_{3}$ & $\mathrm{CH}_{3}$ & $=0$ \\
\hline
\end{tabular}

Alkenoid type

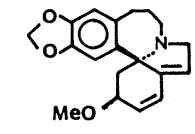

10

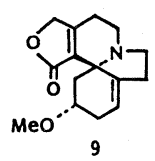

Chart 1

$* *$ 金沢大学薬学部

** Faculty of Pharmacentical Sciences, Kanazawa University

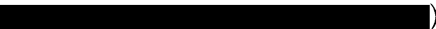


Table 1 Construction of erythrinans via $N$-acyliminium.

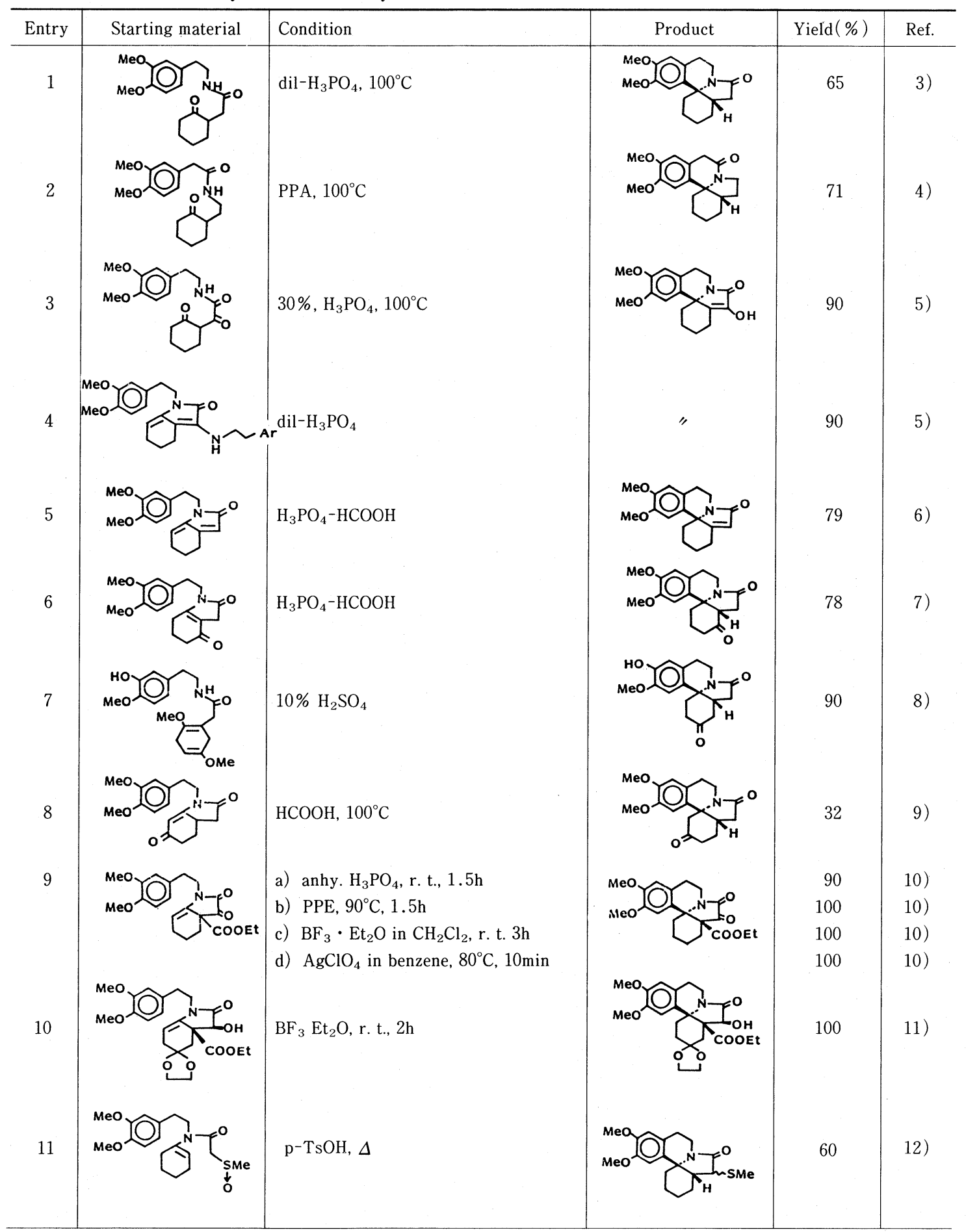


以上のようにエリスリナアルカロイドはその強い生理 作用と, 興味深い構造的特徴を有していることから, 合 成化学者の標的分子として注目され, 多数の合成研究が なされている。以下我々の研究を含めて, エリスリナン 骨格の合成，エリスリナアルカロイドの全合成および非 芳香族アルカロイドの合成に分けて紹介する。

\section{2. エリスリナン骨格の構築}

エリスリナン骨格の合成ルートをその結合形成の最終 ステップでみると，チャート2で示すように，(i) $N-$ arylethylhydroindole の分子内閉環による isoquinoline 環 の形成，(ii) spiroisoquinoline への $\mathrm{C}_{2}$ 単位導入による $\mathrm{B}$ 環形成, (iii) pyrroloisoquinoline $へ の \mathrm{C}_{4}$ 単位の導入 による A 環の形成，(iv) dibenzoazonineの分子内閉環, に分類される。
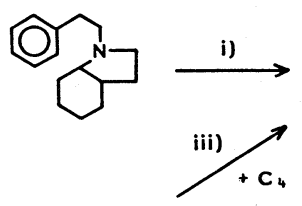

Or

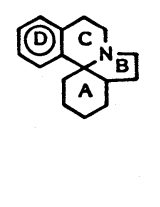

Chart 2
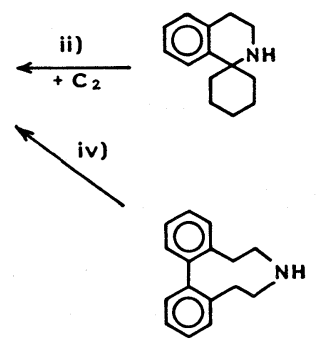

2.1. N-Arylethylhydroindole 誘導体の分子内閉環 $N$-Arylethylhydroindole は arylethylamine と $\gamma$-ketocyclohexanone-2-acetic acid 誘導体の縮合またはcyclohexanone の arylethylamine のエナミンに対するアシル 化による $\mathrm{C}_{2}$ 単位の導入により短工程で合成される。こ れを酸性条件下処理すると, エリスリナンが得られる。 本反応はチャート3で示すように $N$-acyliminium ${ }^{2)}$ に対 する芳香環の求核攻撃による分子内閉環反応である。本 法は Mondon を中心に古くから開発され，多数の合成例 がある(表 1)。

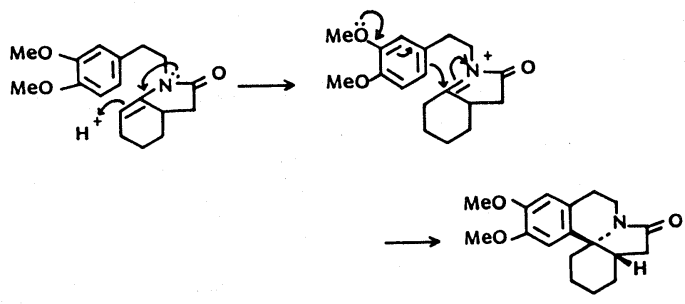

Chart 3

この分子内閉環の縮合例としてリン酸, ギ酸, 硫酸, ヨウ化水素酸などの強い酸が用いられている。高い親電
子性を持つ dioxopyrroline 誘導体は $\mathrm{BF}_{3} \cdot \mathrm{Et}_{2} \mathrm{O}$ や $\mathrm{AgClO}_{4}$ などのルイス酸で容易に閉環しエリスリナンを 与える (entry 9)。この試薬では酸で加水分解されるケ タールを残したままエリスリナンを与える点が利点とな っている(entry 10)。田村らは $\alpha$-sulfenylacetamide を $p$ -TsOH で処理して生じる sulfonium cation, いわゆる Pummerer 反応中間体を経由する興味深いエリスリナン 合成法を報告している(entry 11)。得られたエリスリナ ンはいずれも熱力学的に安定な $\mathrm{A} / \mathrm{B}$ シス配置を持って いる。このことから本閉環反応は熱力学的なコントロー ルをうけていると推定される。この閉環反応では, hyd roindole A 環部位にケトン, エステル，エーテル，アル コールおよび二重結合などの官能基の存在は閉環そのも のに大きな影響を与えない。しかし，化合物 12aでは A 環の芳香化が起こりエリスリナンを与えない13)。この 芳香化は例えば COOEt 基が 6 位に導入された化合物 12bのように 6 位炭素を 4 級化すると防ぐことが出来 る ${ }^{14)}($ チャート 4)。

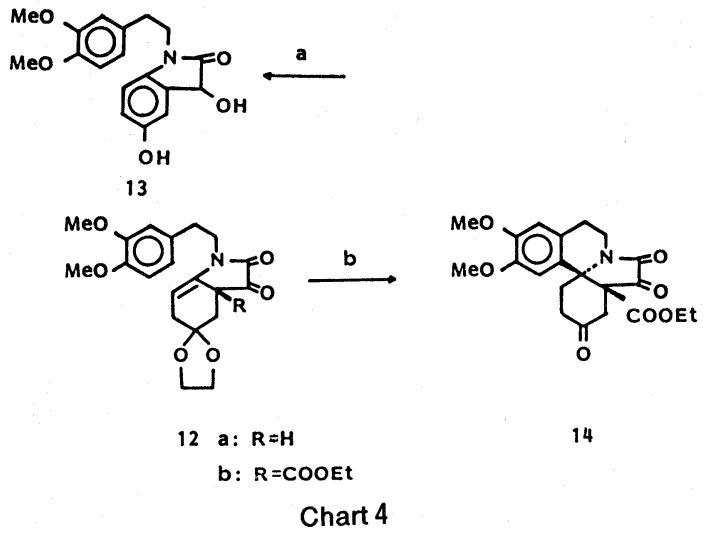

$\beta$ ーケトエステル型に存在する COOEt 基は DMSO 中 $\mathrm{MgCl}_{2}$ と加熱すれば簡単に除去することが出来る ${ }^{411}$ 。よ って本法を組合わせた簡単で適用範囲の広いエリスリナ ン構築法が開発された(チャート5)。

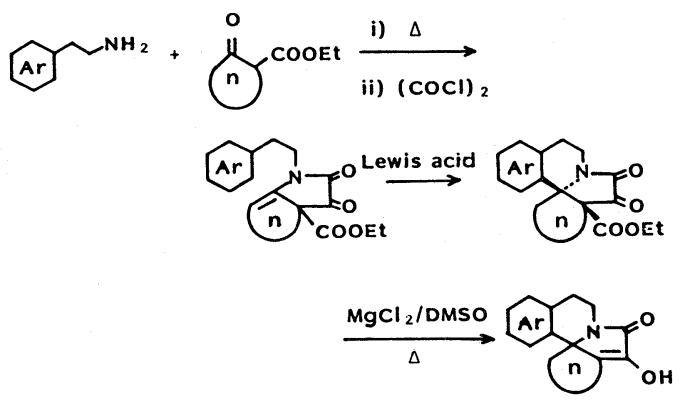

Chart 5 


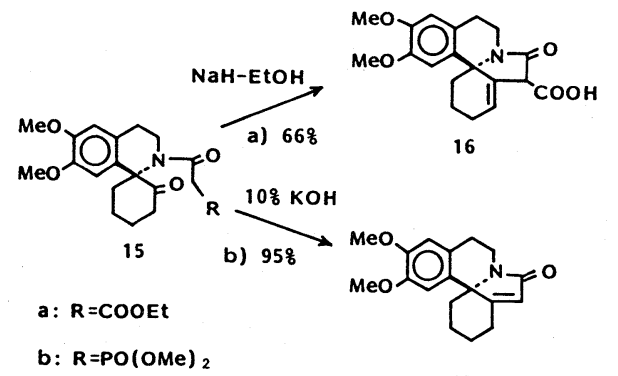

17

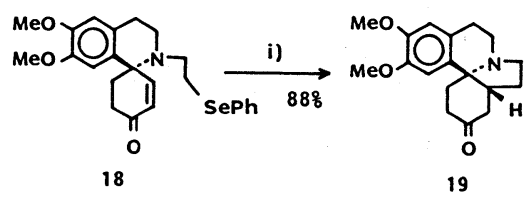

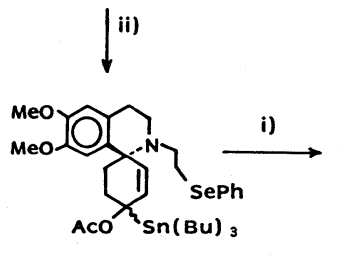

20

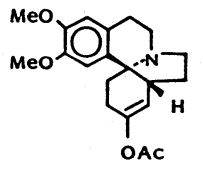

21 i) $(n-B u)_{3} \mathrm{SnH}, \mathrm{AIBN}$ ii) $(n-B u)_{3} \mathrm{SnLi}, \mathrm{AC}_{2} \mathrm{O}$
2.2. Spiroisoquinoline $へ の \mathrm{C}_{2}$ 単位の導入 Cyclohexylspiroisoquinoline 誘導体を適当なアシル化剂でアミ ド 15 を導き, 分子内アルドール縮合㬏あるいは分子内 Wittig 反応 ${ }^{16)}$ で縮合し B 環を形成する。本法は A 環ま たは $\mathrm{B}$ 環に二重結合を持つエリスリナンの合成に適し ている。

Danishefsky ${ }^{17)}$ はラジカル環化法によるエリスリナン の合成を報告している。Selenophenyl 誘導体 18 をベン ゼン中 AIBN の存在下 $(n-\mathrm{Bu})_{3} \mathrm{SnH}$ でラジカルを発生さ せると, 容易に環化が進行し，88\%の収率で2-ケトエ リスリナン 19 が得られる。さらにアセテート 20 を同様 にラジカルを発生させると, 環化が進行しエノールアセ テート 21 が位置特異的に生成する(チャート 6)。

2.3. Pyrroloisoquinoline $へ の \mathrm{C}_{4}$ 単位の導入 最終 ステップにおいて A 環を構築するこのルートはエリス リナアルカロイドの全合成に必要な種々の官能基を $\mathrm{A}$ 環部位に持たせ得る点で注目に值する方法である。Pyr roloisoquinoline のエナミン 22 にメチルビニルケトンを 縮合させると，3-ケトエリスリナン 23 が得られる ${ }^{18)}$ 。 3ーケト体 23 はエリスリナアルカロイドが共通して 3 位 に OMe 基を有する点で合成中間体として注目される(チ ヤート 7)。

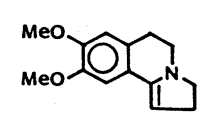

22

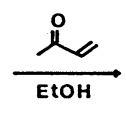

348

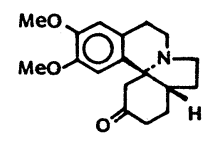

Chart 7

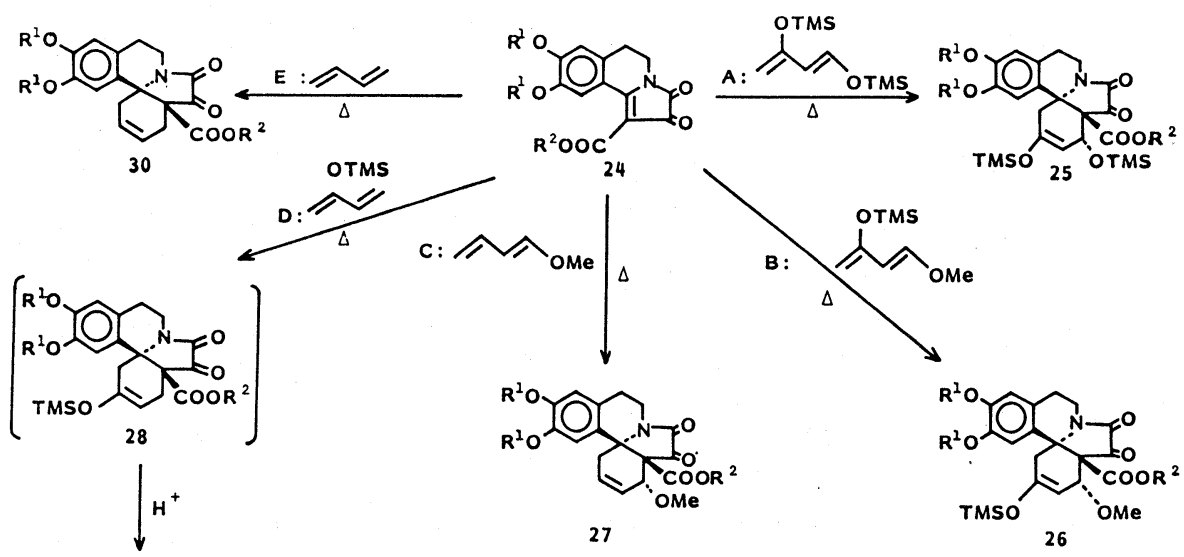

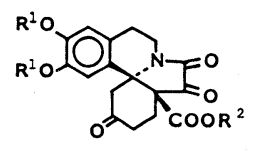

29 a: $R^{1}=R^{2}=$ Me $\quad$ b: $R^{1}-R^{1}=-C_{2}-, R^{2}=M e \quad c: R^{1}=M e, R^{2}=E t$

d: $R^{1}-R^{1}=-C_{2}-, R^{2}=E t$

\section{Chart 8}


Table 2 The Diels-Alder reaction of 24 with butadienes.

\begin{tabular}{c|c|l|c|c|c|c}
\hline Dienophile & Diene & Solvent & Temp $\left({ }^{\circ} \mathrm{C}\right)$ & Time $(\mathrm{h})$ & 1,4 -Adduct & Yield $(\%)$ \\
\hline \multirow{2}{*}{ 24a } & A & Dioxane & 130 & 0.5 & $25 \mathrm{a}$ & 65 \\
& B & Dioxane & 130 & 1 & $26 \mathrm{a}$ & 82 \\
& A & Neat & 130 & 1 & $25 \mathrm{~b}$ & 71 \\
& B & Dioxane & 120 & 1 & $26 \mathrm{~b}$ & 51 \\
& A & Neat & 140 & 1 & $25 \mathrm{c}$ & 58 \\
& B & Neat & 130 & 3 & $26 \mathrm{c}$ & 85 \\
& C & Toluene & 140 & 9 & $27 \mathrm{c}$ & $86^{\text {b) }}$ \\
& D & Toluene & 150 & 17 & $29 c^{\text {a) }}$ & 33 \\
& E & Toluene & 170 & 30 & $30 \mathrm{c}$ & 6 \\
& A & Neat & 130 & 2 & $25 \mathrm{~d}$ & 76 \\
& B & Neat & 130 & 3 & $26 \mathrm{~d}$ & $90^{\text {b) }}$ \\
& C & Toluene & 140 & 5 & $27 d$ & 36 \\
& D & Toluene & 170 & 13 & $29 d^{\text {a) }}$ & 23 \\
& E & Toluene & 170 & 20 & $30 d$ & c) \\
\hline
\end{tabular}

A : 1,3-bis (trimethylsilyloxy)-1,3-butadiene. B : 1-methoxy-3-trimethylsilyloxy-1,3-butadiene

C : 1-methoxybutadiene. D : 2-trimethylsilyloxybutadiene. E : butadiene

a ) After hydrolysis isolated as the corresponding keto compound. b) Yields as crude gum.

c ) Not isolated

Isoquinolinodioxopyrroline 24 とブタジエン類との Diels-Alder (DA) 反応から A 環に種々の官能基が導入さ れたエリスリナンが得られる19)。特に 1,3-bistrimethylsilyloxybutadiene, または 1-methoxy-3-trimethylsilyloxybutadiene との DA 反応は容易にしかも位置及び立体 選択的に進行し, erysotrineなどの dienoid 型アルカロ イドの合成に必要とされる官能基を持ったエリスリナン 25 および 26 を与える(チャート 8)。基質中の COOEt 基 は先に述べた様に容易に取り去ることができる。各種ブ タジエンとの反応条件および結果を表 2 にまとめる。こ の反応では, $\mathrm{CH}_{2} \mathrm{Cl}_{2}$ 等の分極率の大きい溶媒を使用す るか, あるいは反応をより高温で行うと, チャート8に 示した cis-endo 型生成物ではなく, 置換基の立体配置を

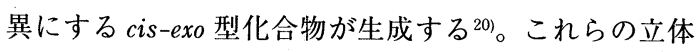
構造は誘導体の X 線結晶解析によって決定した ${ }^{19 a)}$ 。

さらにこの isoquinolinodioxopyrroline 24 から [2+ 2] 型光付加反応を経由するユニークなエリスリナン合 成法が開発された。チャート9で示すように，24 と活 性ジエン類を光反応に付すと，1,2-付加が位置および立 体特異的に進行し, 好収率で vinylcyclobutane 誘導体 31 および 38 が得られる。これを加熱すると，1，3-転位 による環拡大が起こり，エリスリナン 34 抢よび 36 が生 成する ${ }^{21)}$ 。またこれを $n-\mathrm{Bu}_{4} \mathrm{NF}$ でシリル基を切断して アニオンを発生させると ${ }^{22)}$, 極めて低温 $\left(0^{\circ} \mathrm{C} \sim-30^{\circ} \mathrm{C}\right)$ で同様の転位反応が進行する ${ }^{23)}$ 。本反応では基質によっ てカゴ型化合物 40 が副生する。これは 1,2 転位を伴う
ビニル基と 7 位ケトンとの分子内プリンス反応によると 説明される ${ }^{24)}$ 。従って 7 位ケトンを還元したアルコール 体 32 または 39 について $n-\mathrm{Bu}_{4} \mathrm{NF}$ で処理するとエリス リナン 35 または 37 をそれぞれ好収率で得ることが出来 た ${ }^{23)}$ このようにして得られたエリスリナンの A 環の 官能基の配置は Diels-Alder 反応を経由して得られるエ リスリナンとは互いに位置異性体の関係にある点に注目 していただきたい。

\subsection{Dibenzoazonine の分子内環化反応 Dibenzoa-} zonine はエリスリナアルカロイドの生合成中間体である ことが証明されている ${ }^{25)}$ 。従って本法は生合成ルートを 模した方法といえる。Bis-arylethylamine 41 をフェリシ アン化カリウムで酸化すると, 一挙に erysodienone 43 を与える ${ }^{26)}$ 。本品はフェノールの酸化的カップリング反 応によって生じる dibenzoazonine 42 を経由して生成す るものである。事実 dibenzoazonine 42, 44 および 46 を フェリシアン化カリウムで酸化すると, 好収率でエリス

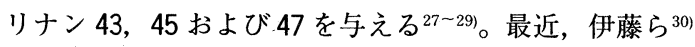
は dibenzoazonine 48 を Birch 還元してエノールエーテ ル 49 とし, ついで酸で処理して, エリスリナン 50 を得 ている(チャート 10)。

2.5. その他のアプローチ 分子内電子環化反応によ るエリスリナンの合成が報告された ${ }^{31)}$ 。Acyldihydroisoquinoline 51 trimethylsilylmethyl triflate でアルキル化 し， CsF で処理すると，エリスリナン 53 を与える。こ れらは中間に発生する $\alpha$-ketoiminium ylide 52 の分子内 

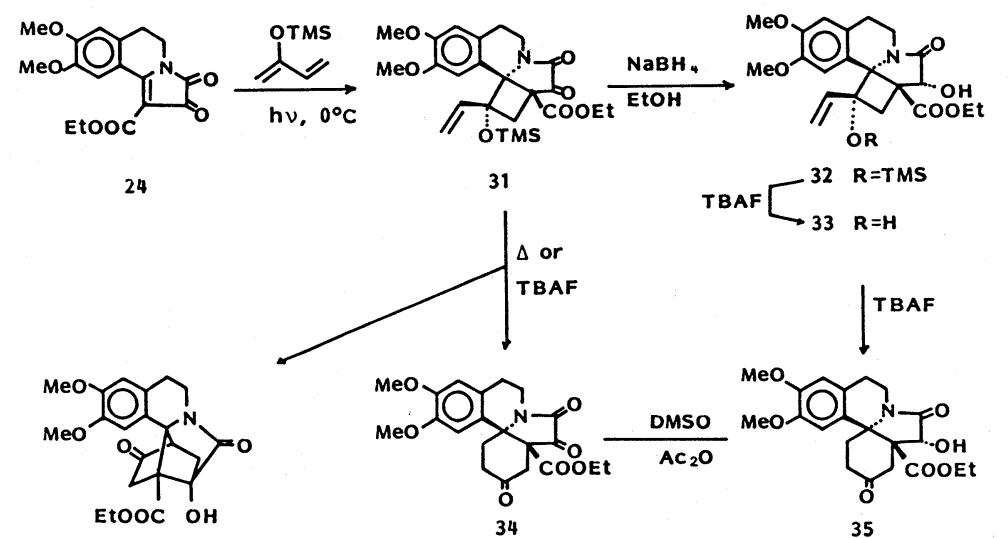

24

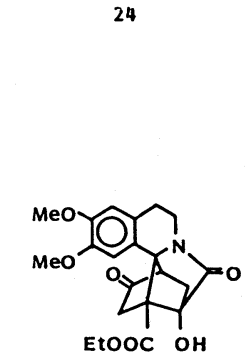

40
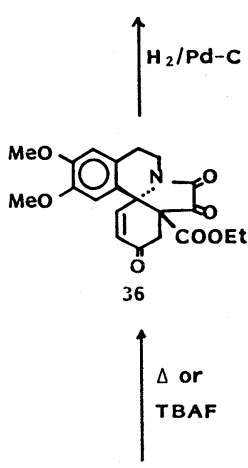

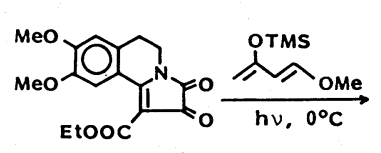

24

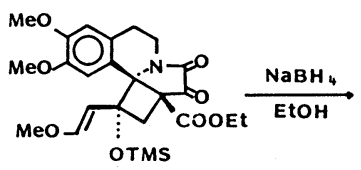

38
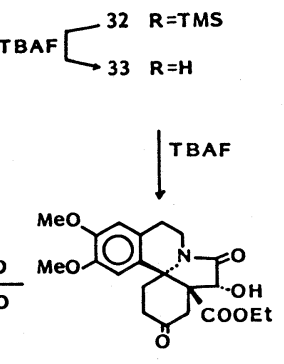

35

$\left\lceil\mathrm{H}_{2} / \mathrm{Pd}-\mathrm{C}\right.$

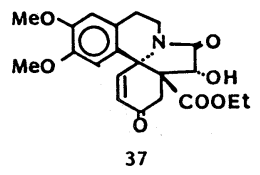

TBAF

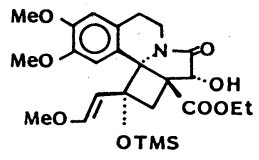

39

Chart 9

[2+3] 環状付加反応と説明される。類似のアセチレン 誘導体 54 も同様にエリスリナン 55 を与える(チャート 11)。

\section{3. ホモエリスリナン骨格の合成}

ホモエリスリナン骨格の構築はエリスリナンの場合と 比較するとはるかに困難で，エリスリナン合成で成功し た方法を適用してもよい結果を与えない場合が多い。チ ヤート 12 で示す例のように56のフェノールカップリン グ反応 ${ }^{32)}$, benzazepinodioxopyrroline 58 の Diels-Alder 反応 ${ }^{33)}, N$-arylpropylhydroindole $61^{12)}$ および $63^{34)}$ の分 子内閉環反応など，いずれも低収率で天然物合成には利 用できない。

しかし，ホモエリスリナアルカロイドの生合成径路に 類似した dibenzoazecine の閉環は比較的よい結果を与え るようである。例えば 65 をフェリシアン化カリウムで
酸化すると，ホモエリスリナン 66 を $60 \%$ の収率で ${ }^{35)}$, また 67 Birch 還元し, 酸で処理するとホモエリスリ ナン 68 を 79\%の収率で与える ${ }^{36)}($ チャート 13)。しかし これらのルートも dibenzoazecine に至るまでの収率が悪 く，天然物の全合成に応用することは困難である。

我々はチャート 14 で示すように先にのべたジオキソ ピロリンの $[2+2]$ 型光付加反応を経由するエリスリナ ン骨格合成法がホモエリスリナンの合成にも好収率で適

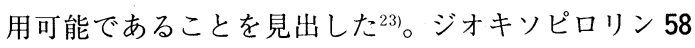
に 1-methoxy-3-trimethylsilyloxybutadiene を光付加さ せると, cyclobutane 誘導体 69 を好収率で与える。これ を $\mathrm{NaBH}_{4}$ で還元，アルコール体 70 を $\mathrm{Bu}_{4} \mathrm{NF}$ で処理す ると期待通りホモエリスリナン 71 が好収率で生成し た。これを接触還元すると2-ケトホモエリスリナン 72 が得られる。 

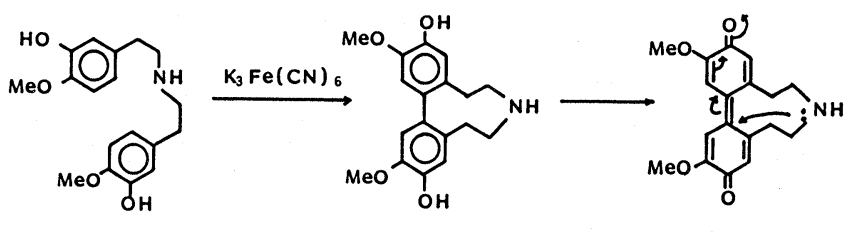

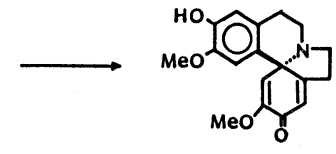

43

358 from 41

808 from 42

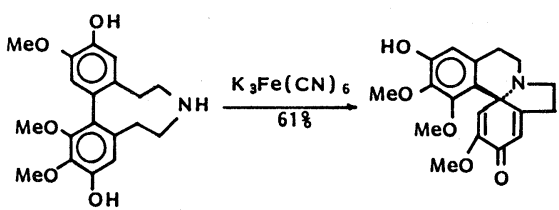

44<smiles>COc1ccc(CCNCCc2cc(O)ccc2O)c(O)c1</smiles>

48

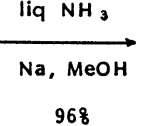

968

45

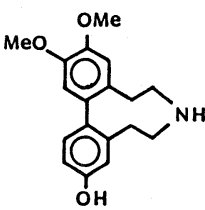

46

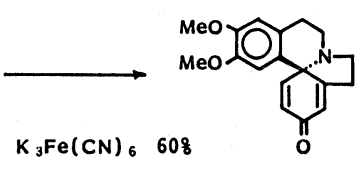

$\mathrm{PbO}_{2} \quad 658$

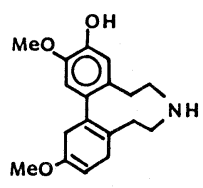

49

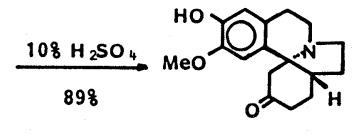

50

Chart 10

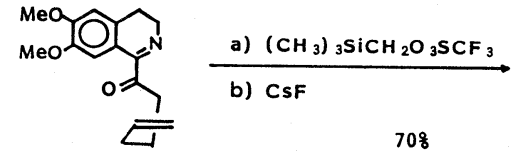

51

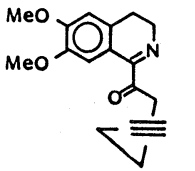

54

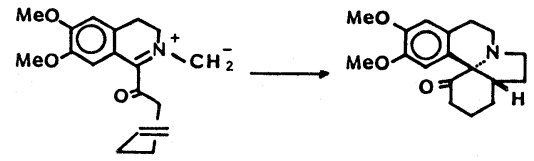

52
53

\section{4. エリスリナアルカロイドの全合成}

エリスリナアルカロイドの全合成の最も困難な仕事は いかにして $\mathrm{AB}$ 環に官能基を導入するかである。ここで はこの問題を中心に論ずる。

4.1. Dihydroerysodine の全合成 フェノールカッ

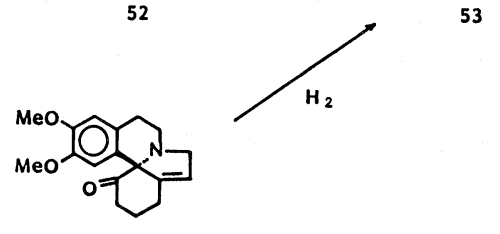

Chart $11 \quad 55$

プリングによって得られる erysodienone 43 は, dihydroerysodine 76 へ誘導されている26a)。43を $\mathrm{NaBH}_{4}$ で還 元後, 塩酸で処理すると, erysotinone 74 を与える。再 び $\mathrm{NaBH}_{4}$ で還元後アルコール 75 とし, クロル化, 接触 還元すると dihydroerysodine 76 を与える(チャート 15)。

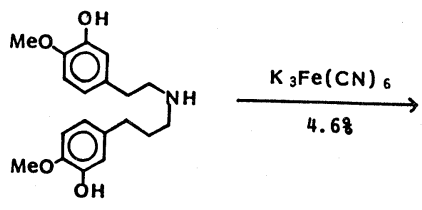

56

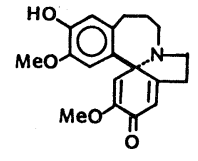




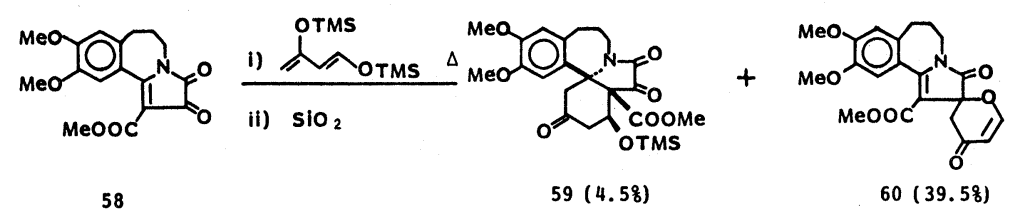

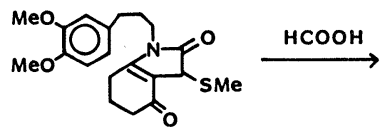

61

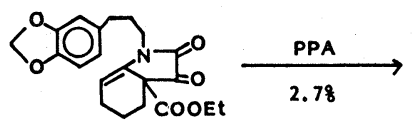

63

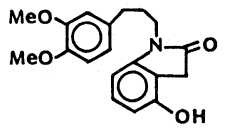

62

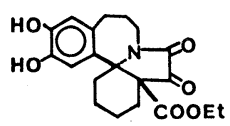

64

Chart 12

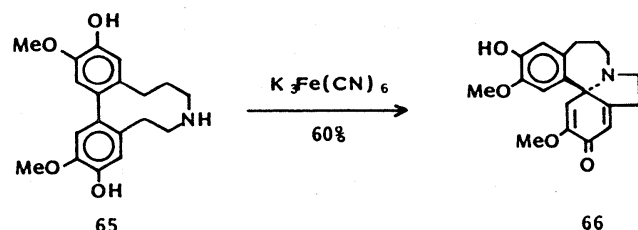
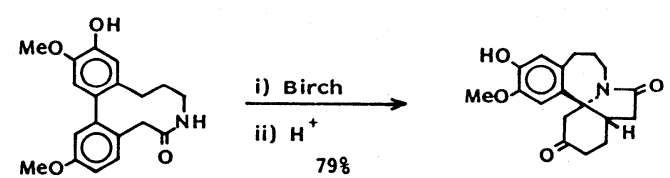

66

68

Chart 13

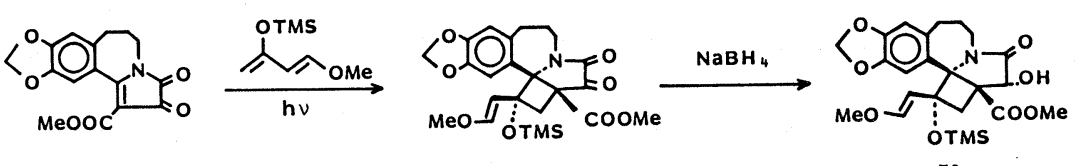

58

69

70

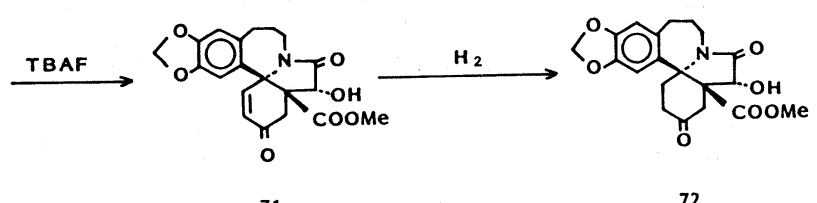

Chart 14

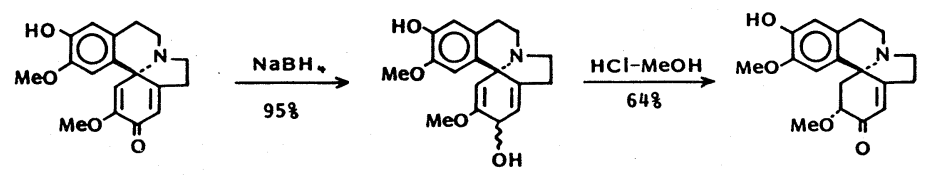

43

73

74

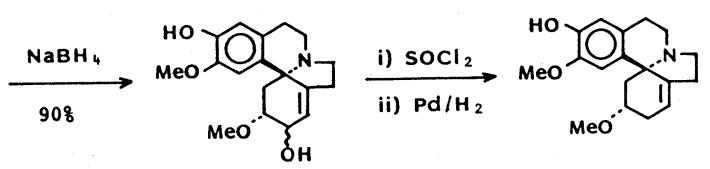

75 


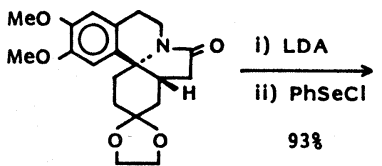

80

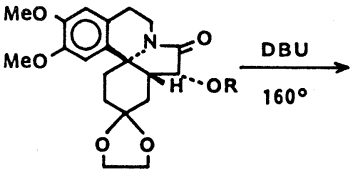

77<smiles>CCN1C(=O)[C@@]23C[C@H]4[C@H]1C(=O)CC[C@]42c1cc(OC)c(OC)cc13</smiles>

82

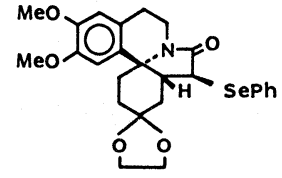

81

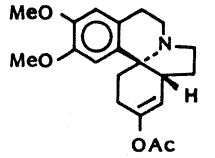

21

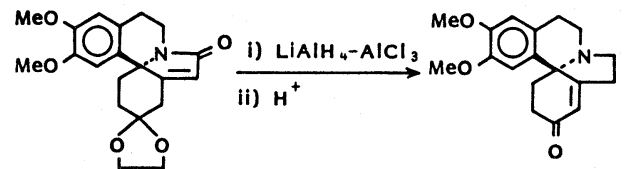

79

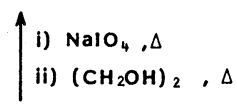

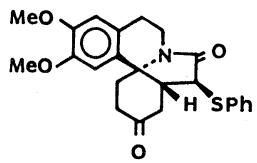

83

Chart 16

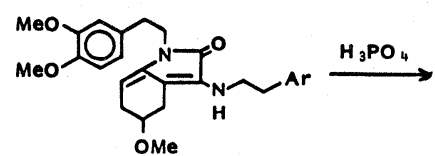

84

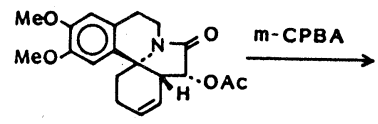

87

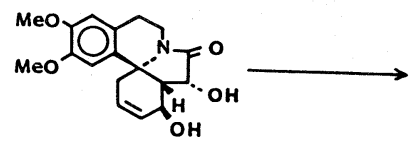

90

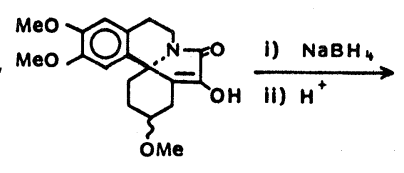

85

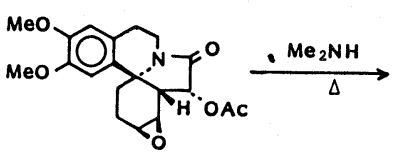

88

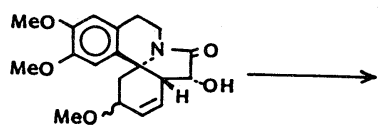

91

a : $\alpha$-OMe

b: $\beta$-OMe

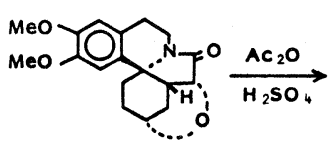

86

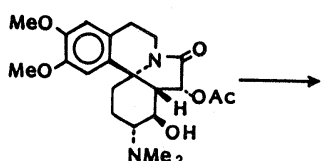

89

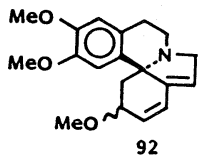

92

b: $\beta$-OMe

Chart 17

4.2. 3-Demethoxyerythratidinone の全合成 3-Demethoxyerythratidinone 79 は最も簡単な構造のエリスリ ナアルカロイドであり, 津田ら ${ }^{37}$ は種々の 2-ケト体か らその合成を達成している。2,8-Dioxo-7 $\alpha$-hydroxyerythrinan 77 をメシル化後，DBUでメシル基を脱離す ると 78 を与える。ついで $\mathrm{LiAlH}_{4}-\mathrm{AlCl}_{3}$ でラクタムを還
元, ついでケタールを加水分解すると, 二重結合も異性 化し79が得られる。その他の方法としては 8-オキソ体 80 を $\mathrm{PhSeCl}$ と反応させ， 7 位に $\mathrm{PhSe}$ 基を導入し，つ いで過ヨウ素酸で酸化的に SePh 基を脱離させ 78 を得 る方法もある。また, 1,7-cycloerythrinan 82 を PhSNa で処理すると, シクロプロパン環が開裂し， 7 位に $\mathrm{SPh}$ 
基が導入される。SPh 基を酸化的脱離反応に付すと先の 78 を与える。また dienone 47 は接触還元によって 79 と なる30)。さらにラジカルの環化によって得られるエノー ルアセテート 21 は phenylselenenylation を経由する二重 結合導入により 79 となる ${ }^{17}($ チャート16)。

4.3. Erysotrine の全合成 Mondon ${ }^{38)}$ による erysotrine の全合成がエリスリナアルカロイドの全合成の最初 の例である。 $N$-Arylethylhydroindole 84 の閉環によっ て得られるエリスリナン 85 を還元後, 酸で処理すると 環状エーテル 86 となる。これを $\mathrm{Ac}_{2} \mathrm{O}-\mathrm{H}_{2} \mathrm{SO}_{4}$ 中加熱す るとオレフィン 87 を与える。ついでエポキシ化, ジメ チルアミンで開環してアミノアルコール 89 とし， $N-$ oxide を経由してアミンを脱離するとアリルアルコール 90 が得られる。これをメ夕ノール中酸性条件下で処理 すると，アリル転位が起こり 3-OMe 体 91a およびその 異性体 $91 \mathrm{~b}$ が他の 3 種の生成物と共に得られる。これ らをそれぞれ $\mathrm{LiAlH}_{4}$ 還元, ついで 7 位水酸基を脱離 し, erysotrine 1 および 3-epierysotrine 92b とした。本 法においてはアリル転位の段階に選択性が全くないため 目的の化合物の収率が極めて低い。この点が本法の最大 の弱点となっている(チャート17)。

つぎに, 伊藤 ${ }^{39}$ らは erysotrine の 8-オキソ体 erysotramidine 4 の全合成に成功している。2,8-Dioxoerythrinan 誘導体 80 (表 1, entry 7)の 7 位をヒドロキシル化 し, ついでメシル化, ケタールの加水分解, さらにアル カリで処理すると 2,8-dioxo-1,7-cycloerythrinan 82 が 得られる。この 2 位のカルボニル基をチオケタール化 し, $\mathrm{PhSeCl}$ で処理するとシクロプロパン環の開裂と同 時に 3 位に $\mathrm{Cl}$ 基が導入されたアリルクロリド体 95 およ び共役ジエン体 96 を与える。前者の $\mathrm{PhSe}$ 基を酸化的
に脱離すると定量的に 96 に導きうる。 3 位の $\mathrm{Cl}$ 基は $\mathrm{AgNO}_{3}$ 存在下 $\mathrm{MeOH}$ で処理すると, 立体選択的に $\mathrm{OMe}$ 基と置換し 97 を与える。これを脱硫すると, erysotramidine 4 となる (チャート 18)。この合成におけるジチ オケタールの $\mathrm{PhSeCl}$ 処理による $\mathrm{Cl}$ 基の導入反応はケト ンの $\alpha$ 位への官能基の導入法として注目に值する。

我々は二つの方法で erysotrine 1 の全合成に成功し た。第一は, isoquinolinodioxopyrroline 24 の DielsAlder 体 25 より出発するものである ${ }^{19 b, 40)}$ 。DA 体 25 の $\mathrm{AB}$ 環の官能基は dienoid 型アルカロイドの合成に非常 に都合のよい配置をしている。例えばエノールシリル エーテルを加水分解すると共役ケトン 101 を与えると予 想される。しかし，実際には25を酸で処理するとA 環 が開裂し A-seco 体 102 を与える。本反応は 1,5-ジケト 系における逆 Michael 反応によるものと考えられたの で， $\mathrm{LiBH}_{4}$ で 7 位のケトンのみを選択的に還元し，つい でエノールエーテルを加水分解したところ, 目的の共役 ケトン 103 が好収率で得られた。これをメシル化, つい で $\mathrm{MgCl}_{2}$ の存在下 DMSO 中加熱すると ${ }^{41)}$, 脱 COOMe と同時に脱 OMs が起こり，ジエノン体 104 を与える。 この反応は先に述べた $\beta$-ケトエステル類の脱エステル 化の拡張である。この場合は $\beta$-ケトエステルビニロー グから脱エステル化が起こり, 中間に生成するジエンエ ノレートから更に脱 OMs 化が起ったものである。これ を Meerwein-Ponndorf 還元すると $\alpha$-アルコール体 105a およびその異性体 105b がそれぞれ 70\% および 25\%の 収率で得られる。これらをメチル化するとそれぞれ erysotramidine 4 およびその 3-epi 体 106b 与える。これを さらに $\mathrm{AlH}_{3}$ で還元すると erysotrine 1 およびその 3-epi 体 92b を与えた。本法は homoveratrylamineより 10 行

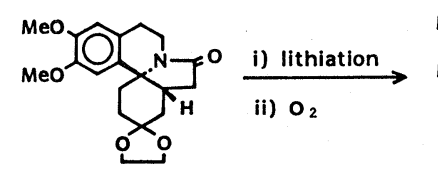

80

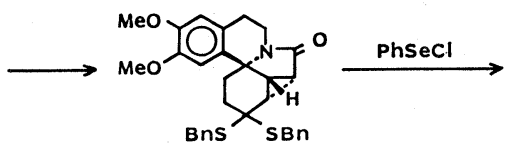

94

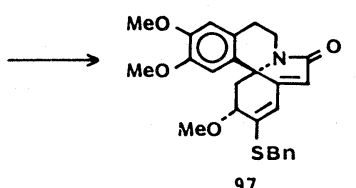

97
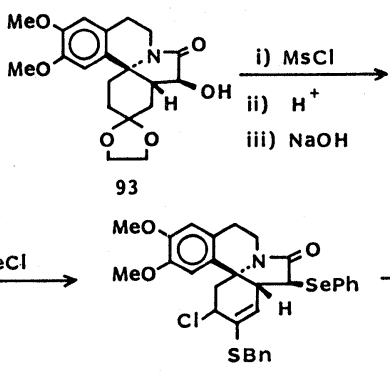

95

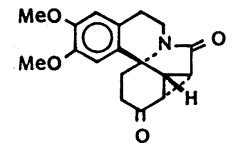

82

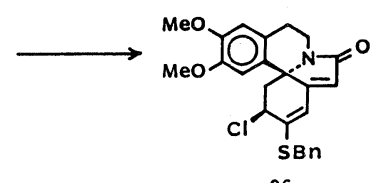

96

Chart 18 


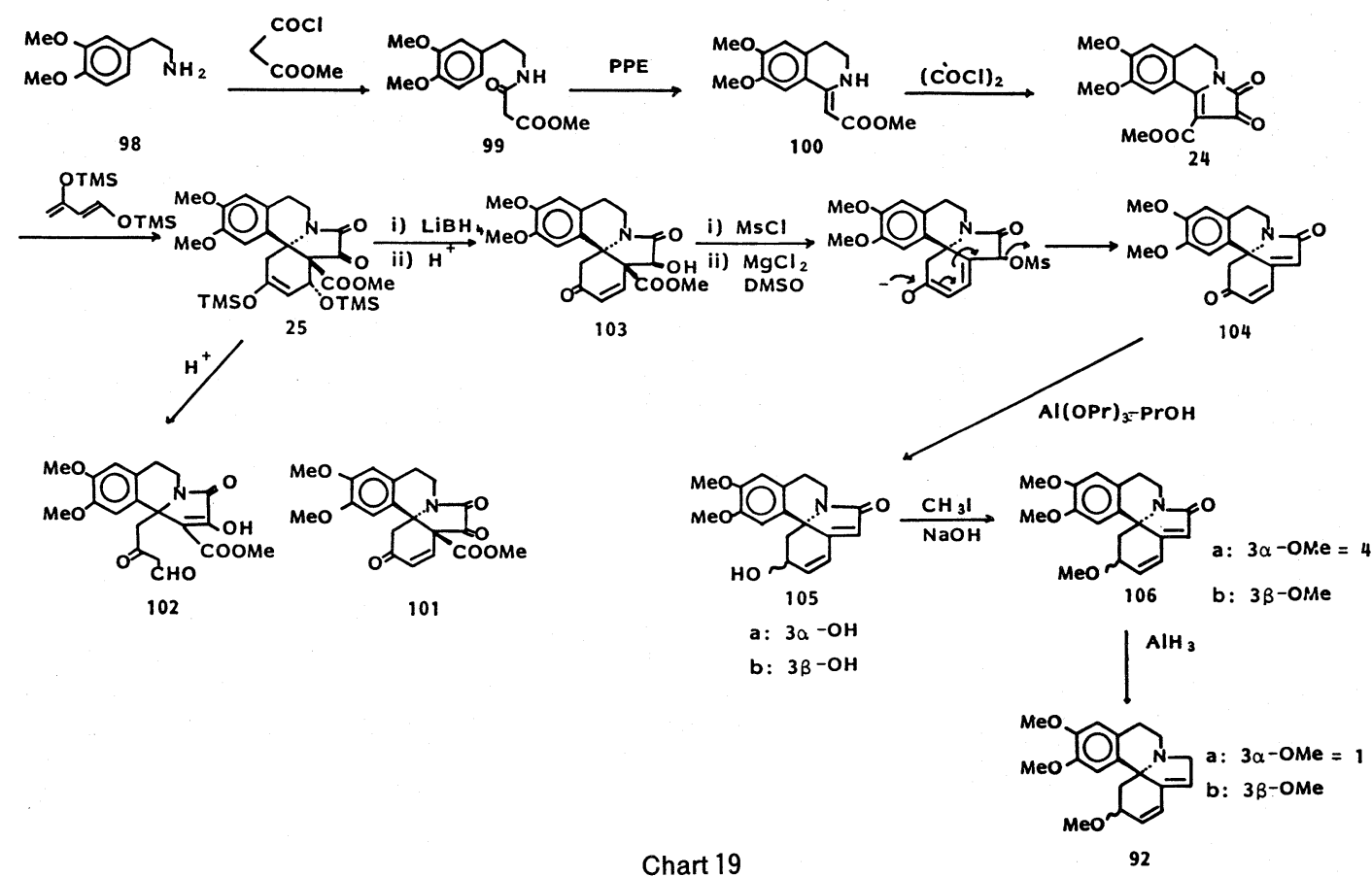

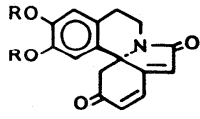

104

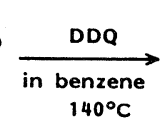

$140^{\circ} \mathrm{C}$

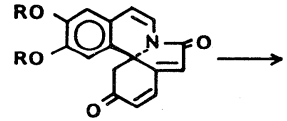

107

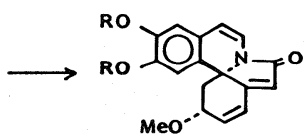

108

a: $\mathrm{R}=\mathrm{CH}_{3}, \mathrm{~b}: \mathrm{R}-\mathrm{R}=-\mathrm{CH}_{2}-$

Chart 20

程全収率 $10 \%$ 強であり，この種のアルカロイドの合成 としては著しく高い収率で，充分に実用的である(チ ヤート 19)。同様の方法で erythraline 3 が合成された。

またジエノン 104 を DDQ 酸化すると, C 環に二重結 合が導入され 107 をえる。これより高度に不飽和の工 リスリナアルカロイド erytharbine 108a および crystamidine 108b が合成された ${ }^{42)}($ チャート20)。

我々はさらに phenylselenenylationを経由する新しい 1,2-carbonyl transposition 法を開発し43)，別ルートによ る erysotrine 1 の合成に成功した ${ }^{44)}$ 。エリスリナン 109 （表 1, entry 10）は分子内アルキル化を経由して容易に 1,7-cycloerythrinan 110 に導くことが出来る。これを $\mathrm{THF}$ 中触媒量の $\mathrm{BF}_{3} \cdot \mathrm{Et}_{2} \mathrm{O}$ 存在下 $\mathrm{PhSeCl}$ で酸化し, つづいてメタノール中当量の $\mathrm{Hg}\left(\mathrm{ClO}_{4}\right)_{2}$ で処理する と， $\alpha, \alpha$-ジメトキシケトン体 111 となる。これを $\mathrm{NaBH}_{4}$ で還元，エチルエステルをメチルエステルに交 換後, ジチオカルボネートにかえ, $\mathrm{Bu}_{3} \mathrm{SnH}$ で還元する と, ジチオカルボニル基のラジカル的脱離と同時に, シ
クロプロパン環の開裂が起こり, つづいて酸加水分解す るとエノシ 113 が得られる。ついで $\mathrm{CaCl}_{2}$ の存在下へプ チルメルカプタンを含有した DMSO 中加熱して脱 COOMe すると, 非共役ケトン 114 と共役ケトン 115 が $5: 1$ の割合で生成する。前者を DBU で処理すると, 定 量的に後者に異性化する。114を DDQ 酸化すれば先の ジエノン 104 に導きうる。ここで形式的に erysotrine 1 の全合成が完了したことになる(チャート 21)。この酸 化の収率はあまりよくない $(24 \%)$ 。

一方, 共役ケトン 115 は同様な DDQ 酸化で 104 を与 えずに 116 をえる ${ }^{44)}$ 。従って，まず 115 を $\mathrm{NaBH}_{4}$ $\mathrm{CeCl}_{3}$ で還元, $\mathrm{NaH} / \mathrm{CH}_{3} \mathrm{I} / \mathrm{Bu}_{4} \mathrm{NHSO}_{4}$ でメチル化して 117 とし,これを $\mathrm{LDA} / \mathrm{PhSeCl}$ でセレネニル化後, 酸化 的に脱 $\mathrm{PhSe}$ 化し，好収率で erysotramidine 4 を得た (チャート 21)。

本法の開発によって $\mathrm{A}$ 環の官能基の位置の異なる出 発物から，天然アルカロイドの合成が可能となった。

\subsection{Coccuvinine の全合成 Coccuvinine 122は16位}



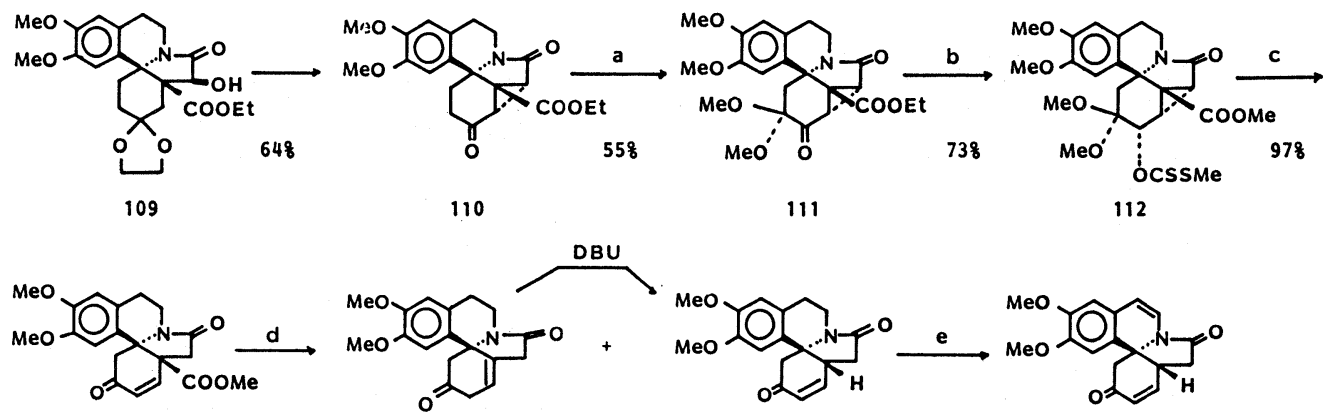

113

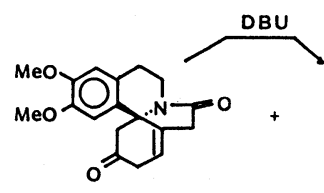

114
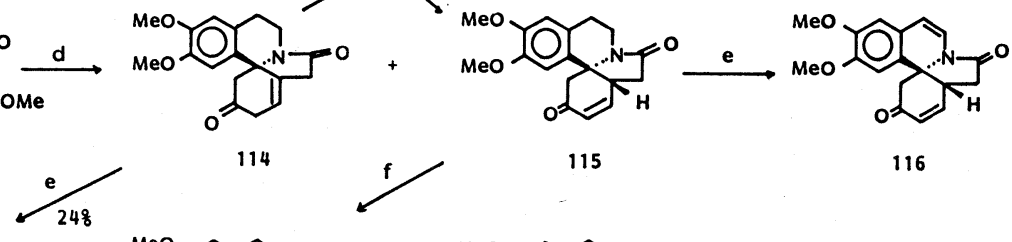

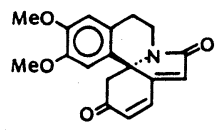

104

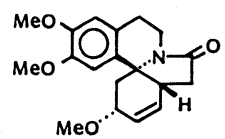

117
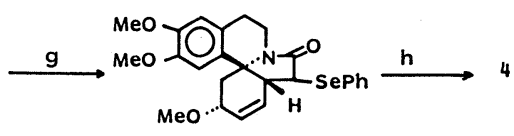

118

a: i) $\mathrm{PhSeCl}$, ii) $\mathrm{Hg}\left(\mathrm{ClO}_{4}\right)_{2}-\mathrm{MeOH}$. b: i) $\mathrm{NaBH}_{4}$ ii) $\mathrm{NaOCH}_{3}-\mathrm{MeOH}$ iii) $\mathrm{NaH} / \mathrm{CS}_{2}, \mathrm{Mel}$.

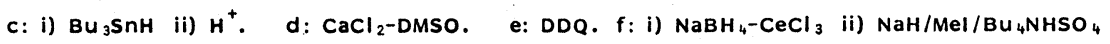

g: PhSeCl/LDA. h: $\mathrm{NaIO}_{4}$

\section{Chart 21}

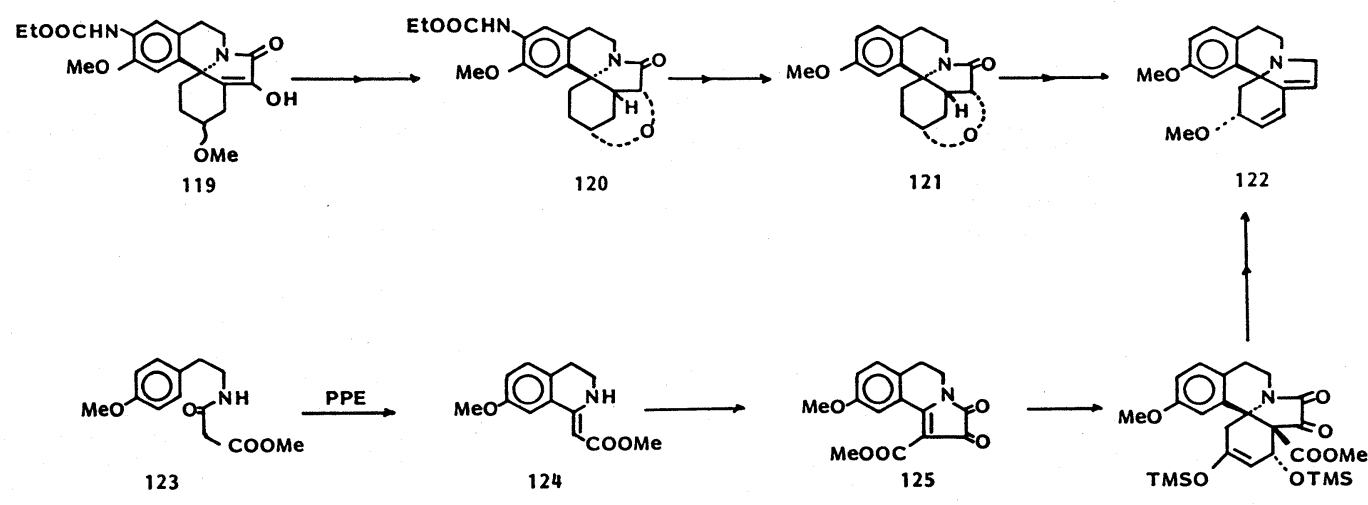

Chart 22

に酸素官能基を持たない“abnormal”タイプとよばれる エリスリナアルカロイドである。この合成にはイソキノ リン環形成に扔いて 15 位 OMe 基のメ夕位の活性化をう けていない位置への閉環が要求される。十一ら cuvinine の最初の全合成に成功しているが，彼らは 16 位に NHCOOEt 基を持つ $N$-arylethylhydroindole から Mondon 法によって 120 を得，ついで NHCOOEt 基を除 去して 121 に導き，この問題を解決している。 $\mathrm{AB}$ 環に おける官能基の修飾は Mondon の erysotrine 合成で行わ れた方法で行い coccuvinine 122 に導いている。従って 最終工程の収率は非常に悪い。

我々はアミド 123 を Bischler-Napieralski 反応に付す
と，約 $50 \%$ 収率で直接 isoquinoline 124 を与えることを 見い出した。ついで isoquinolinodioxopyrroline 125 に導 き，先に述べた DA 反応を鍵段階とするエリスリナン合 成法を適用し, coccuvinine 122 を合成した ${ }^{46)}$ (チャート 22)。

\section{5. ホモエリスリナアルカロイドの全合成}

5.1. Schelhammericine 全合成 ホモエリスリナン 骨格の合成はエリスリナン骨格の合成に比してはるかに 困難であることは先に指摘した。我々は schelhammericine 11 および 3-epischelhammericine 132b の全合成に 成功したが48), この成功は広範囲に行ったエリスリナア 


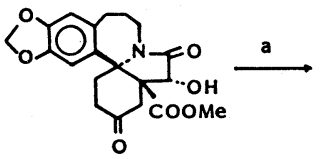

72

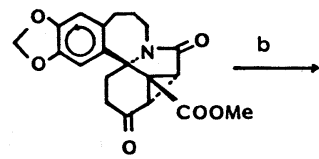

127

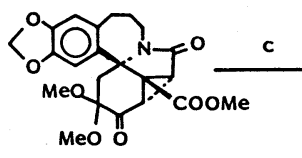

128

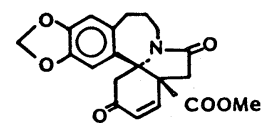

129

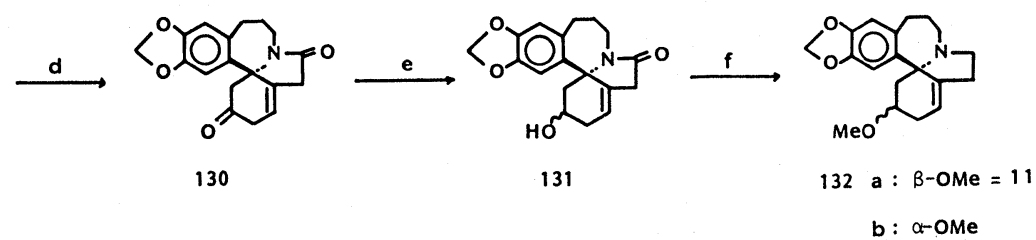

a: i) $\mathrm{MsCl}$, ii) $\mathrm{DBU}$. b: i) $\mathrm{PhSeCl}$, ii) $\mathrm{MPL} / \mathrm{MeOH}$. c: i) $\mathrm{NaBH}_{4}$, ii) $\mathrm{NaH} / \mathrm{CS}{ }_{2} / \mathrm{Mel}$, iii) $n-\mathrm{Bu}_{3} \mathrm{SnH}$, iv) $\mathrm{H}^{+}$

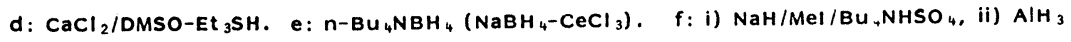

\section{Chart 23}

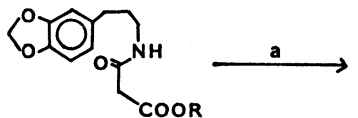

133

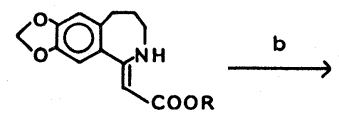

134

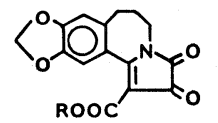

58

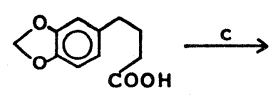

135

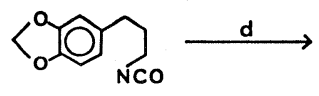

136

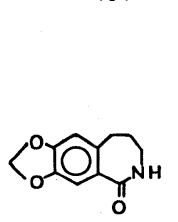

137

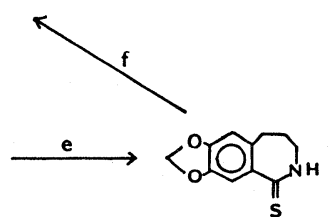

138

a: PPE. b: $(C O C l)_{2}$ /ether. C: i) $E t_{3} \mathrm{~N} / \mathrm{ClCOOEt,} \mathrm{ii)} \mathrm{NaN}_{3}$, iii) $\Delta /$ toluene

d: $\mathrm{POCl}_{3} / \mathrm{SnCl}_{4}$. e: $\mathrm{P}_{2} \mathrm{~S}_{5} /$ benzene. f: i) $\mathrm{BrCH}_{2} \mathrm{COOR}$, ii) $\mathrm{KHCO}_{3}$, iii) $\mathrm{Ph}_{3} \mathrm{P} / \mathrm{t}-\mathrm{BuOK} / \mathrm{DMF}$

Chart 24

ルカロイドの合成研究に基づいている。我々が開発した dioxopyrroline を原料とする 3 つのエリスリナン骨格合 成法, (i)acyliminium を経由する分子内閉環反応, (ii) Diels-Alder 反応, (iii)光付加反応のうち, 先に示したよ うに光付加法のみがホモエリスリナンの合成に有効であ った。

このようにして得たホモエリスリナン 72 を 1,7-cyclohomoerythrinan 127 に導き, $\mathrm{AB}$ 環の官能基の修飾を phenylselenenylation を経由する 1,2-carbonyl transposition 法を適用し, 共役ケトン 129 を得, ついで 3 位ケト ンの還元およびメチル化, さらにラクタムを還元し, schelhammericine 11 およびその 3-epi 体 132bに導いた (チャート23)。

この合成における他の問題点は鍵化合物の一つである benzazepinodioxopyrroline 58 の合成である。例えば isoquinolinopyrrolinedione 24 は amide 99 の BischlerNapieralski 反応経由で容易に得られるが(チャート 19
参照), 同様な反応を amide 133に適用しても, 約 $15 \%$ で benzazepinone 134 を与えるにすぎない49)。そこで 135 から容易に得られる isocyanate 136 を閉環して benzazepinone $137^{50)}$ とし, 更に酢酸ユニットを導入して 134 に導き, 目的の benzazepinodioxopyrroline 58 を得 て,この問題を解決した(チャート24)。

5.2. 6,7-Dihydroschelhammeridine (alkaloid A) の全 合成 6,7-Dihydroschelhammeridine 147a はschelhammericine の二重結合に関する位置異性体である。従って $\beta, \gamma$-不飽和ケトン 130 の二重結合を異性化し共役ケト ン 139 に導けばその合成が可能と考えられる。しかしこ れをDBU 処理したところ 139 ではなく，それがさらに 環拡大し dibenzoazecine 140 となった ${ }^{51)}$ (チャート 25)。 エリスリナンでは同様の異性化で共役ケトンが得られ る44) (チャート 21 参照)。

そこで別法により共役ケトン 139 を導いた52)。ホモエ リスリナン 141 をDMSO- $\mathrm{Ac}_{2} \mathrm{O}$ で酸化し, ついで脱 


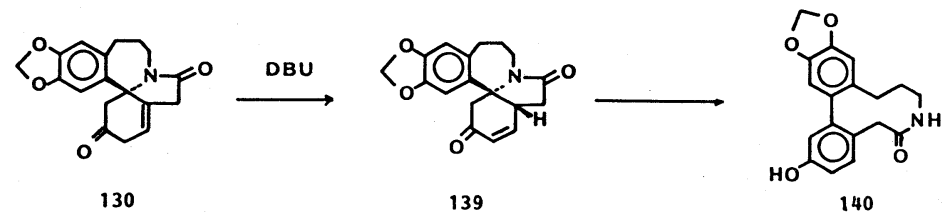

Chart 25

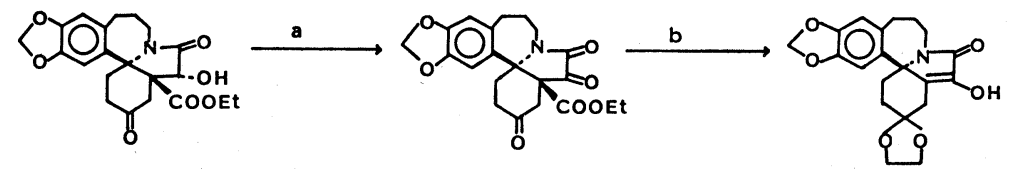

141

142

143

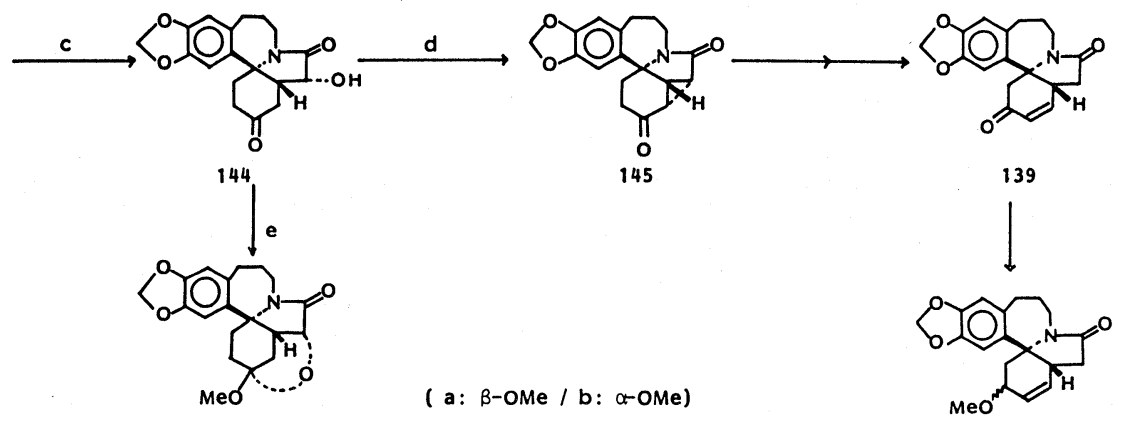

148

a: DMSO-AC ${ }_{2} \mathrm{O}$ b: i) $\mathrm{HOCH}_{2} \mathrm{CH}_{2} \mathrm{OH} / \mathrm{p}-\mathrm{TSOH}$, ii) $\mathrm{MgCl}_{2} / \mathrm{DMSO}-\mathrm{Et}_{3} \mathrm{CSH} / \triangle$

c: i) $\mathrm{NaBH}_{4}$, ii) $\mathrm{HCl} /$ acetone d: i) $\mathrm{MsCl} /$ pyridine, ii) $\mathrm{K}_{2} \mathrm{CO}_{3} / \mathrm{MeOH}$

e: $\mathrm{MeOH} / \mathrm{p}-\mathrm{TSOH}$

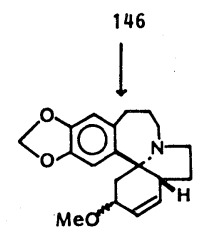

Chart 26

147

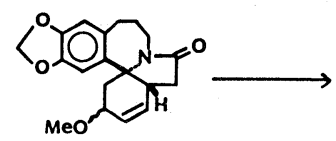

146

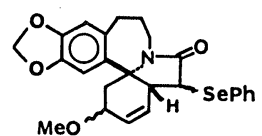

149

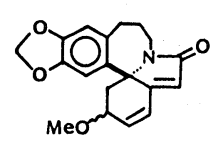

150

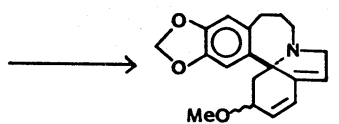

151

$(151 a=10)$

Chart 27

COOEt し，還元するとアルコール144を与える。これ を 1.7-cyclohomoerythrinan 145 に導き, phenylselenenylation を経由する方法で目的の 139 を得た。こ れを $\mathrm{NaBH}_{4}-\mathrm{CeCl}_{3}$ で還元すると, エリスリナンの場合 とは異なり(エリスリナンでは $3 \alpha-\mathrm{OH}$ 体を生成する) $3 \beta-$
$\mathrm{OH}$ 体を多く生成した。さらにメチル化, ラクタムの還 元によって 6,7-dihydroschelhammeridine 147a (alkaloid A) および 3-epi 体 147b (comosine) が合成された。この 合成が行われるまで, これらアルカロイドの $\mathrm{A} / \mathrm{B}$ 環の 立体配置はトランスと推定されていた。しかし, 本合成 
中間体の化合物 144 はケタール 148 を形成することから 明らかに A/B はシス配置を持っている。途中その配置 が変る恐れのない方法でこれらのアルカロイドが合成さ れているので，その立体配置はシスと訂正された(チ 十ート 26)。

\subsection{Schelhammeridine の全合成 上の合成の中間} 体 146 を $\mathrm{PhSeCl} / \mathrm{LDA}$ と反応させ，更に酸化的に $\mathrm{PhSe}$ 基を除去すると, ジエノイド型化合物 150 となる。これ を $\mathrm{AlH}_{3}$ で還元し schelhammeridine 10 および 3-epischelhammeridine 151b が合成された(チャート 27) ${ }^{53)}$ 。

\section{6. 非芳香族エリスリナアルカロイドの合成研究}

非芳香族エリスリナアルカロイドはエリスリナアルカ ロイドの $\mathrm{D}$ 環の芳香環が酸化的開裂をうけ生合成され るものと考えられている ${ }^{54)}$ 。現在のところその骨格合成 に関する報告があるにすぎない。

6.1. $\beta$-Erythroidine 骨格の合成 $\beta$-Erythroidine 8 は $\mathrm{D}$ 環に不飽和 $\delta$-ラクトンを有している。北原ら ${ }^{55}$ は エリスリナンからの誘導を行っている。彼らは16-メト キシエリスリナン 152 を Birch 還元して, cyclohexenone 誘導体 153 とし, ベンズアルデヒドを縮合，つい でオゾン酸化して環開裂を行い，ケトエステル155に導 いている。Dimethyloxosulfonium methylide で炭素一ヶ を導入してエポキシドにし，ついでラクトン化し $\beta$ -erythroidine の骨格 156 を得たと報告している。
しかし，最近磯部ら ${ }^{56}$ は別法により同じ化合物をつぎ の 2 法で合成しているが，北原のそれに一致しなかっ た。第一の方法は，15,16,17-トリメトキシエリスリナ ン 157 をオゾン酸化して D 環を開裂し158 を得，酢酸 でエノールエーテルを，ついでアルカリでエステルを加 水分解し, さらに $\mathrm{NaBH}_{4}$ で還元して, ラクトンカルボ ン酸 159 に変換する。これを $\mathrm{NH}_{4} \mathrm{OH}$ アルカリ中光照射 すると, 脱炭酸が起こり $\beta$-erythroidine の骨格 160 と なる。

また磯部らは D 環がフラン環となったエリスリナン 161 からその環を酸化的に変換して $\gamma$-ラクトン体 162 を導き，接触還元，アルカリ加水分解，メチル化してケ トーメチルエステル 163 の 2 種の立体異性体を得てい る。これをWittig 反応，および $\mathrm{SeO}_{2}$ 酸化でヒドロキシ ル化した後アリル転位と同時にラクトン化し，化合物 160 を合成した(チャート 28)。この二つの合成では全く 同一の化合物 160 が得られるが，これは北原らの 156 に は一致しない。また，第2の合成ルートの途中で得られ るケトーメチルエステル 163 は 2 種の立体異性体のいず れもが北原らの中間体 155 に一致しなかった。一体 156 はどのような構造のものだろうか。現在サンプルが失わ れているので，云々すべくもないが，その反応過程を追 試した結果では $153 \rightarrow 154$ の過程に問題があるようであ る。

6.2. Cocculolidine 骨格の合成 Cocculolidine 9 は

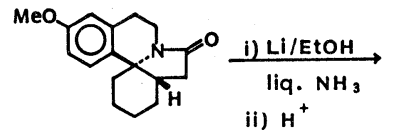

152

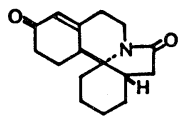

153

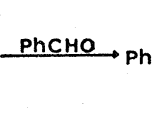

(1)

154 ii) $\mathrm{H}_{2} \mathrm{O}_{2}$

iii) $\mathrm{CH}_{2} \mathrm{~N}$

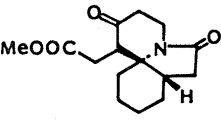

155

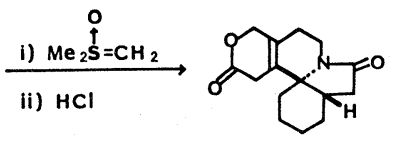

156

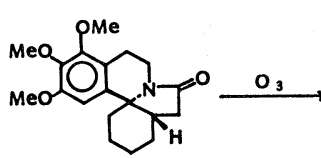

157

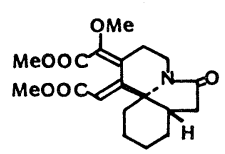

158 i) $\mathrm{CH}_{3} \mathrm{COOH}$

ii) $\mathrm{NaOH}$ iii) $\mathrm{NaBH}_{4}$

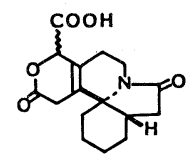

159

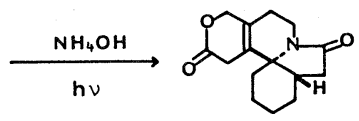

160

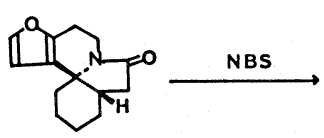

161

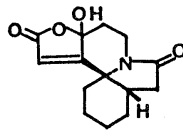

162

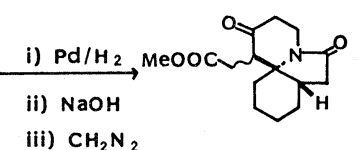

iii) $\mathrm{CH}_{2} \mathrm{~N}_{2}$
163

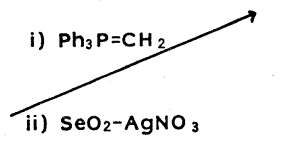

iii) $\mathrm{H}^{+}$

Chart 28 

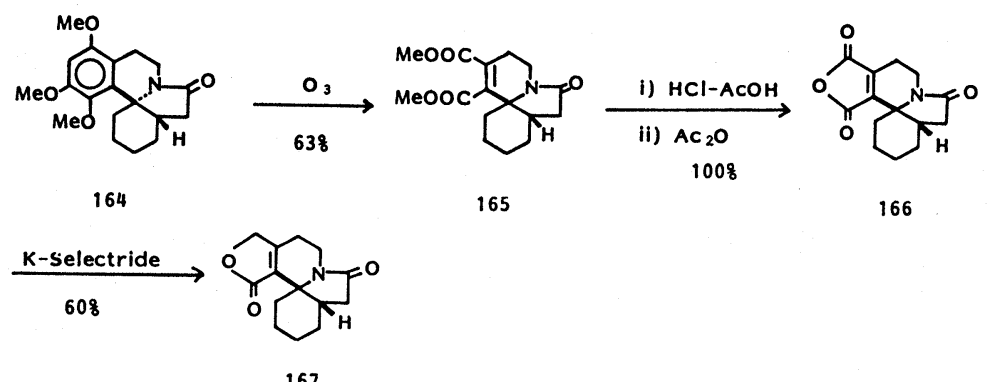

165

166

\section{Chart 29}

$\mathrm{D}$ 環が $\gamma$-ラクトンとなったアルカロイドで, ッッ゙ラフ ジ科の Cocculus 属植物より得られ, 昆虫に対する摂食 阻害活性が報告されている。磯部ら ${ }^{57}$ は芳香環のオゾン 酸化による開裂法を適用し，その骨格化合物を合成して いる。即ち，14,15,17-トリメトキシエリスリナン 164 をオゾン酸化すると, ジエステル 165 が得られる。これ を酸無水物 166 にし, K-selectride で還元を行い, その 骨格化合物 167 入導いた。本法は cocculolidine 骨格合 成の最初の例である(チャート29)。

\section{7. 結語}

以上エリスリナアルカロイドの合成研究を紹介した。 比較的構造の簡単なアルカロイドではあるが, その全合 成に至る成功例をみると，そこには必ず新しい合成手法 の開発または導入がなされている。Mondonの acyliminium を経由するエリスリナンの構築, 我々の行った dioxopyrroline に対する Diels-Alder 反応，あるいは [2 +2] 型光反応を経由するエリスリナンの合成などの骨 格構築法, 一方官能基の修飾では $\beta$-ケトエステル類の 中性条件下での脱エステル法や phenylselenenylation を 経由する 1,2-carbonyl transposition 法の開発がその全 合成に大きく貢献している。ホモエリスリナアルカロイ ドの全合成はこれら手法の集大成の結果によるものであ る。

（昭和62年 5 月 18 日受理）

\section{文献}

1) S. F. Dyke, S. N. Quessy, "The Alkaloids" edited by R. G. A. Rodrigo, Vol 18, p1, 1981, Academic Press.

2） $N$-acyliminium を経由する合成研究が W. N. Spekamp らを中心に広くなされている。〔W. N. Spekamp, H. Hiemsta, Tetrahedron, 41, 4367 (1985)]

3) A. Mondon, Chem. Ber., 92, 1461 (1959)

4) B. Belleau, Can. J. Chem., 35, 651 (1957)

5) A. Mondon, Liebigs Ann. Chem., 628, 123 (1959)

6) A. Mondon, J. Zander, H. U. Menz, ibid., 667, 126 (1963)
7) A. Mondon, K. Bötter, Chem. Ber., 103, 1512 (1970)

8) M. Haruna, K. Ito, J. Chem. Soc., Chem. Commun., 1976, 345

9) T. Oh-ishi, I. Iijima, N. Itoh, S. Sugasawa, Chem. Pharm. Bull., 23, 2573 (1975)

10) Y. Tsuda, Y. Sakai, M. Kaneko, Y. Ishiguro, K. Isobe, J. Taga, T. Sano, Heterocycles, 15, 431 (1981)

11) Y. Tsuda, Y. Sakai, M. Kaneko, K. Akiyama, K. Isobe, ibid., 16, 921 (1981)

12) H. Ishibashi, K. Sato, M. Ikeda, H. Maeda, S. Akai, Y. Tamura, J. Chem. Soc., Perkin Trans 1, 1985, 605

13) A. Mondon, K. F. Hansen, K. Bochme, H. P. Faro, H. J. Nestlar, H. G. Vilhuber, K. Bättcher, Chem. Ber., 103, 615 (1970)

14) Y. Tsuda, Y. Sakai, T. Sano, Heterocycles, 15, 1097 (1981)

15) S. Sugasawa, H. Yoshikawa, Chem. Pharm. Bull., 8, 290 (1960)

16) Y. Zhang, S. Takeda, T. Kitagawa, H. Irie, Heterocycles, 24, 2151 (1986)

17) S. J. Danishefsky, J. S. Panek, J. Am. Chem. Soc., 109, 917 (1987)

18 a) R. V. Stevens, M. P. Wentland, Chem. Commun., 1968, 1104

b ) J. B. Bremmer, C. Drager, Heterocycles, 23, 1451 (1985)

19 a ) T. Sano, J. Toda, N. Kashiwaba, Y. Tsuda, Y. Iitaka, Heterocycles, 16, 1151 (1981)

b) T. Sano, J. Toda, N. Kashiwaba, T. Ohshima, Y. Tsuda, Chem. Pharm. Bull., 35, 479 (1987)

20) Y. Tsuda, T. Oshima, T. Sano, J. Toda, Heterocycles, 19, 2027 (1982)

21) T. Sano, J. Toda, Y. Horiguchi, K. Imafuku, Y. Tsuda, ibid., 16, 1463 (1981)

22) T. Sano, J. Toda, Y. Tsuda, Chem. Pharm. Bull., 31, 2960 (1983)

23) T. Sano, J. Toda, Y. Tsuda, T. Oshima, Heterocycles, 
22, $49(1984)$

24) T. Sano, J. Toda, Y. Tsuda, ibid., 22, 53 (1984)

25) D. H. R. Barton, R. James, G. W. Kirby, D. A. Widdowson, Chem. Commun., 1967, 266

26 a ) A. Mondon, M. Ehrhardt, Tetrahedron Lett., 1966, 2557

b ) J. E. Gervay, F. MeCapra, T. Money, G. M. Sharma, Chem. Commun., 1966, 142

27) D. H. R. Barton, R. James, G. W. Kirby, D. W. Turner, D. A. Widdowson, J. Chem. Soc.(C), 1968, 1529

28) B. Frank, V. Teetz, Angew. Chem. Internat. Ed., 10, 411 (1971)

29) H. Tanaka, M. Shibata, K. Ito, Chem. Pharm. Bull., 32, 1578 (1984)

30) H. Tanaka, M. Shibata, K. Ito, ibid., 32, 3271 (1984)

31) M. Westing, R. Smith, T. Livinghouse, J. Org. Chem., 51, 1159 (1986)

32) T. Kametani, K. Fukumoto, J. Chem. Soc.(C), 1968, 2156

33) Y. Tsuda, T. Ohshima, T. Sano, J. Toda, Heterocycles, 19, 2053 (1982)

34) Y. Tsuda, unpublished results.

35 a ) McDonald, A. Suksamran, Tetrahedron Lett., 1975, 4425

b ) J. P. Marino, J. M. Samanen, J. Org. Chem., 41, 179 (1976)

36) H. Tanaka, Y. Takamura, M. Shibata, K. Ito, Chem. Pharm. Bull., 34, 24 (1986)

37) Y. Tsuda, A. Nakai, K. Ito, F. Suzuki, M. Haruna, Heterocycles, 22, 1817 (1984)

38 a ) A. Mondon, H. J. Nestler, Angew. Chem., 76, 651 (1964)

b ) A. Mondon, H. J. Nestler, Chem. Ber., 1979, 1329

39) K. Ito, F. Suzuki, M. Haruna, J. Chem. Soc., Chem. Commun., 1978, 733
40) T. Sano, J. Toda, Y. Tsuda, Heterocycles, 18, 229 (1982)

41) Y. Tsuda, Y. Sakai, Synthesis. 1981, 119

42) Y. Tsuda, S. Hosoi, F. Kiuchi, T. Sano, J. Toda, R. Yamamoto, Heterocycles, 22, 2255 (1984)

43) Y. Tsuda, S. Hosoi, Chem. Pharm. Bull., 33, 1745 (1985)

44) Y. Tsuda, S. Hosoi, A. Nakai, T. Ohshima, Y. Sakai, F. Kiuchi, J. Chem. Soc., Chem. Commun., 1984, 1216

45) Y. Tsuda, unpublished results.

46) M. Ju-ichi, Y. Fujitani, Y. Ando, Chem. Pharm. Bull., 29, 396 (1981)

$47)$ T. Sano, J. Toda, N. Maehara, Y. Tsuda, Can. J. Chem., 65, 94 (1987)

48) Y. Tsuda, S. Hosoi, T. Ohshima, S. Kaneuchi, M. Murata, F. Kiuchi, J. Toda, T. Sano, Chem. Pharm. Bull., 33, 3574 (1985)

49) T. Sano, Y. Tsuda, unpublished results.

50) T. Fushimi, H. Ikuta, H. Irie, K. Nakadachi, S. Uyeo, Heterocycles, 12, 1131 (1979)

51) Y. Tsuda, M. Murata, F. Kiuchi, Chem. Pharm. Bull., 34, 3910 (1986)

52) Y. Tsuda, M. Murata, Tetrahedron Lett., 27, 3385 (1986)

53) Y. Tsuda, The 5th French-Japanese Symposium on Medicinal and Fine Chemistry, 1986, May

54) D. H. R. Barton, R. D. Bracho, C. J. Potter, D. A. Widdowson, J. Chem. Soc., Perkin Trans. 1, 1974, 2278

55) T. Kitahara, M. Matsui, Agr. Biol. Chem., 38, 171 (1974)

56) K. Isobe, K. Mohri, Y. Itoh, Y. Toyokawa, J. Taga, Y. Tsuda. Chem. Pharm. Bull., 35, 2618 (1987)

57) K. Isobe, K. Mohri, M. Maeda, T. Takeda, Y. Tsuda, ibid., 35, 2602 (1987) 